\title{
QUALITY MANAGEMENT IN HIGHER EDUCATION: THE INDIVIDUAL WORK OF STUDENTS' QUALITY MANAGEMENT
}

\author{
OLENA GUBARENKO \\ Luhansk National Taras Shevchenko University, \\ (C) $(\mathbb{D} \Theta \Theta$ \\ State service and management of educational and social establishments, \\ 2 Oboronna str., Luhansk 91011, Ukraine \\ E-mail address: helen-hubarenko@mail.ru
}

\begin{abstract}
The importance of this article is dictated by the necessity to adopt the Bologna standard of higher education including the module system into the frame of the Ukrainian university network. The author gives a brief review of the development of the quality concept and approaches, which have been made to integrate it into higher education management. The article sets out the new scheme of individual work of student management seen as part of the general management process.
\end{abstract}

Keywords: individual work of students, quality management, higher education management

\section{INTRODUCTION}

The worldwide recognition of the important role of the professional competences of a specialist is accompanied by dissatisfaction with the modern education system today, the crisis that has already been identified and recognized as a reality in Ukrainian society. The growing mismatch between the synergetic character of the education process and the traditional knowledge paradigm of the teaching process dictates the necessity to change the paradigm of higher education (HE). Having become the part of the Bologna process, Ukraine is adapting those principles to its national education system. One of the differences between European universities and Ukrainian is the realization that the basic education of the student must not take place in an audience, but in the course of active independent work. 


\section{THE DEFINITION OF THE INDEPENDENT WORK OF STUDENTS}

The independent work of students (IWS) is a planned, tutored, checked and monitored process of organizing the individual intellectual activities of students in the course of their HE study. The problems of IWS organization has long been the subject of vivid discussion in Ukrainian, Russian, and European psychological and pedagogical literature. Different authors interpret the phenomenon of IWS as a teaching method (Babanskij, 1989; Usova 1988; Zharaya, 1999), a form of training (Esipov, 1961; Shamova, 2002), a specific type of training activity (Zimnyaya, 2003, Mandinach \& Sharnell, 2012), a means of study (Pidkasistyj, 2004), the basis of self-education (Aisenberg, 1996, Serikov, 1989); synthetic form of training and cognitive activities (Dolzhenko, Shatunovskij, 2005), a set of teaching strategies (Como, 1986, Mandinach, 1983, Schank, 1997); a self-regulated transformation of knowledge tranformaton (Zimmerman, 2000); one of the forms of competence (Levy-Leboyer, 2002, Weinert, 2001). Supervising the process of the individual students work organization as a part of the general university management is the new approach to the IWS organisation this article claims to discuss (Gubarenko, 2013).

\section{COMPETENCE BASED EDUCATION}

In national pedagogical science the competence approach is used to describe the result of a learning process. Therefore, the general target of a program of study in higher education has changed from the obtaining a certain amount of knowledge, to the formation of certain professional competences (Figure 1). Professional competence consists of a number of specific competences based on the development of "key" and "basic" skills. This development is provided via student-teacher interaction on the structural, theoretical and practical levels, resulting in the student's growing autonomy in finding the information and solving the profession-related problems. The definitions of the competence varies from one discipline to another, but always includes "the development of students' intellectual and imaginative powers, their understanding and judgment, their problem-solving skills, their ability to communicate, their capability to see the relationship within what they have learned and to perceive their field of study in a broader perspective. The modern program aims to stimulate an enquiring, analytical and creative approach, encouraging independent judgment and critical self-awareness" (Khrykov, 2006). All of the above mentioned abilities can only be obtained through the individual student's activity, which nowadays is verified from one-third to two-thirds of an overall university curriculum (according to Higher Education Law of Ukraine, 2012). The importance of the individual work of students is obvious, but the quality of this self-maintained activity is low due to the lack of systematic approaches, which different teachers introduce for different subjects. 


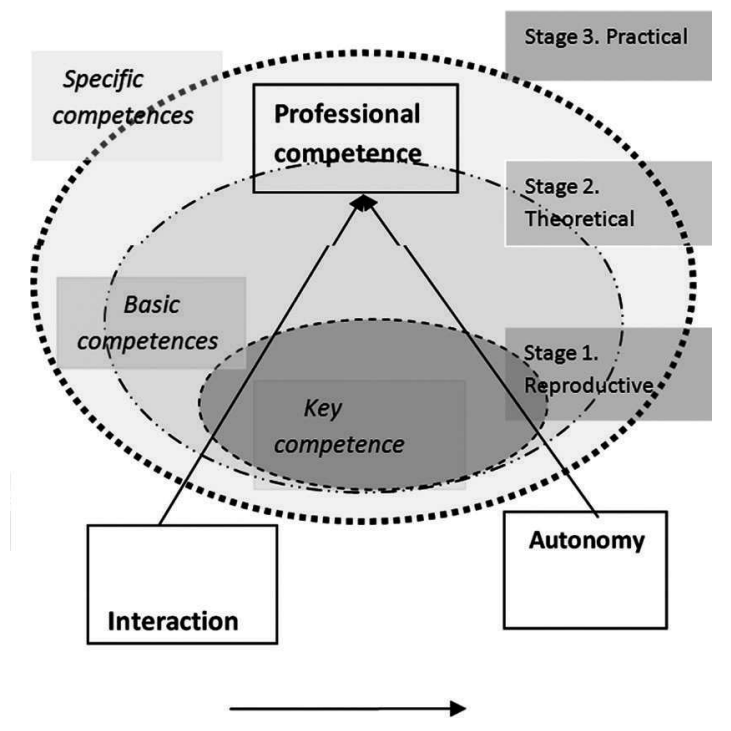

Fig.1. Formation of professional competence during IWS

Source: author
The number of students has significantly increased in Ukraine; the distribution of the student population is becoming steadily wider and more diverse in terms of age, nationality, basic skills and other characteristics. The teachers and students are under increasing pressure to more fully exploit the flexibility of the modular system which encourages them to vary the pace of study, and enables them to complete a degree curriculum via fast-tracking in a shorter period of time. On the other hand, the implementation of the new Credits/Modules structure of the curriculum does not completely match Ukrainian universities resources (materials, finances, methodology) to provide the maintenance of the new technology and the volumes of the individual students work in particular.

\section{THE MANAGEMENT MODELS IN HIGHER EDUCATION}

The constantly increasing volume of information requires the intensification of educational process and effective management in training. In the United States it has been calculated that the deadline of the professional knowledge ageing (the so-called half-life competence barrier) is less than 5 years; which means that as a result of new information and technology, the competence of a specialist has been reducing $50 \%$ within this period and needs renewal (Winter, 1999). Thus, the system of higher education (HE) must be ready to meet the necessity to get this new knowledge and information in the most effective way for both universities and learners.

The concept of HE reformation in Ukraine has defined the priorities of professional education, including strengthening the role of independent work of students and the increasing responsibility of teachers for developing students' skills of working independently in the course of study. But the educational process at the universities is not only the teachers' responsibility, but also the management of the educational establishment. In consideration of those political and economical changes in the country of which we have spoken, what is absolutely required now is a matching process between students' needs, institutional resources, and teachers' readiness to work under the impact of environmental changes. So we can come to a logical conclusion that the process of organizing the individual students' work must be regarded as one of the 
objectives of the management of the university. The management of higher education is in its turn surviving great historical changes, among which are the following:

- a shift from the administrating policy of total control to Total Quality Management (TQM) in HE;

- the break up of the traditional bureaucratic infrastructure into quasiautonomous corporate educational units;

- a strong emphasis on cost-cutting alongside with enhancing the quality of education.

Latterly, the focus on quality is beginning to revolutionize the management system of most organizations (Berry, 1991; Atkinson \& Kaplan, 2005). David Hutchins (1992) noted that many people did not fully understand the overall quality concept and experience difficulty in relating it to a certain management styles. Unfortunately, quality itself is still an ambiguous term since it has connotations with both excellence and standards. Quality can be considered as fitness for purpose but there are also other definitions such as "conformity to requirements" (Crosby, 1994), or "predictable degree of uniformity at the lowest cost and suited to the market" (Deming, 1994). Ellis in his turn suggested that as the purpose of teaching is learning, then the quality of teaching is its fitness for the purpose of promoting learning (Ellis, 1993). Quality may also be judged by outcomes or performance indicators (Tam, 2006). John Ruskin advocated that the quality is never an accident; it is always the result of intellectual effort (Ruskin, 1884). The development of the quality approach can be represented in short with the following chart [Table 1]:

Table 1. The development of the quality concept throughout a century

\begin{tabular}{|l|l|}
\hline Period & \multicolumn{1}{|c|}{ Concept } \\
\hline Before 1905 & Quality as an integral part of trading and crafts \\
\hline $1900-1921$ & Quality control conducted by foremen \\
\hline $1921-1941$ & Inspection-based quality control \\
\hline $1945-1965$ & Statistical process control \\
\hline $1965-1985$ & $\begin{array}{l}\text { Quality assurance/total quality control conducted } \\
\text { by quality departments }\end{array}$ \\
\hline $1985-1992$ & Quality management \\
\hline $1992-2000$ & TQM, the culture of continuous improvement \\
\hline 2000-now & Organization-wide quality management \\
\hline
\end{tabular}

Source: adopted from Edward Sallis's “Total Quality Management in Higher Education", 2005. 
As long as we are concerned with improving the quality of teachers' and students' actions in HE, then it is important to find a definition of what constitutes quality in higher education. It cannot be measured only by the amount of knowledge as we have already discussed the change of value of the knowledge itself, but probably a much wider meaning containing a number of criteria. For example, the Quality Assurance Agency for HE in Britain has expanded the quality assessment from the three-grade system (excellent, satisfactory, unsatisfactory) in 1993 into a six-criteria assessment in 1995: curriculum design, content and organization; teaching, learning and assessment; students progress and achievement; students support and guidance; learning resources; quality enhancement (Milliken\&Colohan, 2004).

The results of teaching assessment are usually given by a numerical score, with grades from one to four awarded for each category with 24 being the maximum number of points available. (one means the objectives set by the subject provider are not met; two means the objectives set by the subject provider are not fully met; three points are given if the objectives set by the subject provider are broadly met; and four is given if the objectives set by the subject provider are clearly met). It is obvious that this form of monitoring can generate lots of dangers of compliance, objectiveness, inappropriateness and ineffectiveness (de Vries, 1997).

Starting from this pioneer experience a great number of other management technologies have been applied to higher education system (Table 2).

Table 2. The transformation of the total quality management concept

\begin{tabular}{|l|l|l|}
\hline Adopted technology & \multicolumn{1}{|c|}{ Author, year } & \multicolumn{1}{|c|}{ Distinctive features } \\
\hline $\begin{array}{l}\text { Excellence Quality } \\
\text { Model }\end{array}$ & $\begin{array}{l}\text { McAdam \& Welsh, 2000 } \\
\text { Pires da Rosa etc., 2003 }\end{array}$ & $\begin{array}{l}\text { empirical research } \\
\text { base, nine-criteria self- } \\
\text { analysis }\end{array}$ \\
\hline Balanced Scorecard & $\begin{array}{l}\text { Kaplan \& Norton, 1992, Chen } \\
\text { \& Yang, 2006, Cheng \& Tam, } \\
1997\end{array}$ & $\begin{array}{l}\text { Performance } \\
\text { indicators linked to } \\
\text { strategy, evaluation } \\
\text { management }\end{array}$ \\
\hline ISO 9000 & Shutler, Crawford, 1998 & $\begin{array}{l}\text { Continuous } \\
\text { improvent, } \\
\text { preventive actions, less } \\
\text { scientific control }\end{array}$ \\
\hline Internal audit & $\begin{array}{l}\text { Reid, Ashelby, 2002, } \\
\text { Becket\&Brookes, 2006-07 }\end{array}$ & $\begin{array}{l}\text { Six dimension } \\
\text { model: internal/ } \\
\text { qualitative/ } \\
\text { quantitative } \\
\text { information, snapshot/ } \\
\text { longitudinal plan }\end{array}$ \\
\hline $\begin{array}{l}\text { Quality dimensions } \\
\text { framework }\end{array}$ & $\begin{array}{l}\text { Owlia \& Aspinwall, 1996, } \\
\text { Motwani \& Kumar 1997 }\end{array}$ & $\begin{array}{l}\text { 30 quality } \\
\text { characteristics similar } \\
\text { to service methods }\end{array}$ \\
\hline
\end{tabular}




\begin{tabular}{|l|c|l|}
\hline Adopted technology & Author, year & Distinctive features \\
\hline Program evaluation & Mizikaci, 2006 & $\begin{array}{l}\text { Considers HE as a in- } \\
\text { put-process-output sys- } \\
\text { tem with social, techni- } \\
\text { cal and management } \\
\text { subsystems }\end{array}$ \\
\hline $\begin{array}{l}\text { Malcom Baldridge } \\
\text { award }\end{array}$ & Arif and Smiley, 2004 & $\begin{array}{l}\text { Strategic and budget } \\
\text { planning, information ser- } \\
\text { vice, benefits can beimme- } \\
\text { diate and long lasting }\end{array}$ \\
\hline TQM-related & $\begin{array}{c}\text { Aly Akpovi, 2001 } \\
\text { Roberts, Tennant, 2003, } \\
\text { Borahan, Ziarati, 2002, } \\
\text { Srikanthan, Dalrymple, } \\
\text { 2003-2004 }\end{array}$ & $\begin{array}{l}\text { Continuous quality } \\
\text { improvement, } \\
\text { leadership, students } \\
\text { support (from five to } \\
\text { fourteen characteristics) }\end{array}$ \\
\hline
\end{tabular}

Source: Gubarenko O. (2012)

Many scientists agree that implementation of the TQM will generate higher quality products, reduce costs, give more satisfied customers and employees, and improved financial performance (Avdijeva \& Wilson, 2002). A number of attempts have been made to combime the ideas of the TQM with other management models to fit best the needs of higher education system (Widrick, Mergen \& Grant, 2002). Application of TQM principles in HE can be roughly categorized into two aspects: human resource management philosophy (SOFT TQM) and process focused management (HARD TQM).

Regarding the concepts of the so-called soft TQM we can compare in Table 3 the benefits of the TQM-related technologies to the principles of a widely used in previous years Administrative Control Model of management in HE in Ukraine (as well as, actually other post-USSR countries):

Table 3. The comparative analysis of the TQM and the Administrative control system

\begin{tabular}{|l|l|}
\hline \multicolumn{1}{|c|}{ TQM in HE } & \multicolumn{1}{|c|}{ Administrative Control } \\
\hline Quality is seen as part of an educational culture & $\begin{array}{l}\text { Quality is seen as an alien } \\
\text { and troublesome initiative }\end{array}$ \\
\hline $\begin{array}{l}\text { Focus on preventing problems in the teaching } \\
\text { process }\end{array}$ & $\begin{array}{l}\text { Focus on detecting problems } \\
\text { in the teaching process }\end{array}$ \\
\hline Has a clear evaluation strategy of education & $\begin{array}{l}\text { Has no systematic evaluation } \\
\text { strategy of the university }\end{array}$ \\
\hline Develops and follows the long-term plans & Short-termplansadministration \\
\hline
\end{tabular}




\begin{tabular}{|c|c|}
\hline TQM in HE & Administrative Control \\
\hline Customer/students-focused policy & $\begin{array}{l}\text { Focused on the internal needs } \\
\text { of the institution }\end{array}$ \\
\hline $\begin{array}{l}\text { Regards quality as means to satisfy customers } \\
\text { (external - students, industries, internal - staff) }\end{array}$ & $\begin{array}{l}\text { Sees quality as a means to cut } \\
\text { costs }\end{array}$ \\
\hline $\begin{array}{l}\text { Has defined the quality characteristics for all stages } \\
\text { and segments of the teaching process }\end{array}$ & $\begin{array}{l}\text { Has not established quality } \\
\text { standards for its departments }\end{array}$ \\
\hline $\begin{array}{l}\text { Has a strategy for quality monitoring of the teaching } \\
\text { process }\end{array}$ & $\begin{array}{l}\text { Lacks the strategic quality } \\
\text { vision of the processes }\end{array}$ \\
\hline $\begin{array}{l}\text { Aims at organization alignment according to its } \\
\text { Mission }\end{array}$ & $\begin{array}{l}\text { Has no distinctive Mission of } \\
\text { the educational establishment, } \\
\text { non-aligned organization }\end{array}$ \\
\hline $\begin{array}{l}\text { All level workers are interested in the quality } \\
\text { enhancement process and the improvement process } \\
\text { involves everybody }\end{array}$ & $\begin{array}{l}\text { Only the administration } \\
\text { corpus is involved in the } \\
\text { improvement process }\end{array}$ \\
\hline $\begin{array}{l}\text { All members have clear vision of their roles and } \\
\text { responsibilities in the educational process }\end{array}$ & $\begin{array}{l}\text { Members are vague about } \\
\text { their roles and responsibilities } \\
\text { in the educational process }\end{array}$ \\
\hline Creativity is encouraged & $\begin{array}{l}\text { Only rules and procedures } \\
\text { are important }\end{array}$ \\
\hline $\begin{array}{l}\text { Is developing quality in line with its own strategic } \\
\text { imperatives (self-assessment mechanisms) }\end{array}$ & $\begin{array}{l}\text { Is examining the quality } \\
\text { of education to meet the } \\
\text { demands of external agencies } \\
\text { (bureaucratic assessment) }\end{array}$ \\
\hline $\begin{array}{l}\text { Treats complaints as an opportunity to learn and } \\
\text { improve the teaching process }\end{array}$ & Treats complaints as nuisance \\
\hline $\begin{array}{l}\text { Senior managers are leading quality in } \mathrm{HE} \text { and } \\
\text { establishing conditions for its maintaining }\end{array}$ & $\begin{array}{l}\text { The managers role is seen as } \\
\text { the only one of control }\end{array}$ \\
\hline $\begin{array}{l}\text { Invests in people (provides a systematic professional } \\
\text { growth) }\end{array}$ & $\begin{array}{l}\text { Is not systematic in its approach } \\
\text { to staff development and actual } \\
\text { high-qualified workers }\end{array}$ \\
\hline
\end{tabular}

Source: Gubarenko O., 2014

As the example of IWS management (targeting what could be done to improve the quality of the individual students work) we can introduce a diagram of the factors (fig.2), which Ukrainian teachers identify as preventing them from conducting the IWS at the desirable level. The investigation has been made in accordance with the Vilfredo Pareto's charts method (Aspers, 2001). The 80/20 Pareto rule states that 80 percent of enterprise problems arise from $20 \%$ - of the processes. The author's reseach of 2012-2014 
covered 79 teachers of the Luhansk National Taras Shevchenko University (Ukraine), who were asked to arrrange the problems they come across in the course of organizing the individual work of students via a questionnaire sent to their e-mails. Among the most troublesome factors the following ten were mentioned as those which cover about $20 \%$ and more of the university teachers' time and concern:

1 - absence of automatic IWS testing base and assessment tools;

2 - no financial motivation;

3 - reports on IWS fulfillment and results are not obligatory;

4 - lack of university material resources;

5 - not aware of IWS new methods and different technologies;

6 - problems and barriers of a psychological character;

7 - students' ignorance;

8 - lack of IT competence;

9 - lack of work experience;

10 - incorrect distribution of the personal working time.
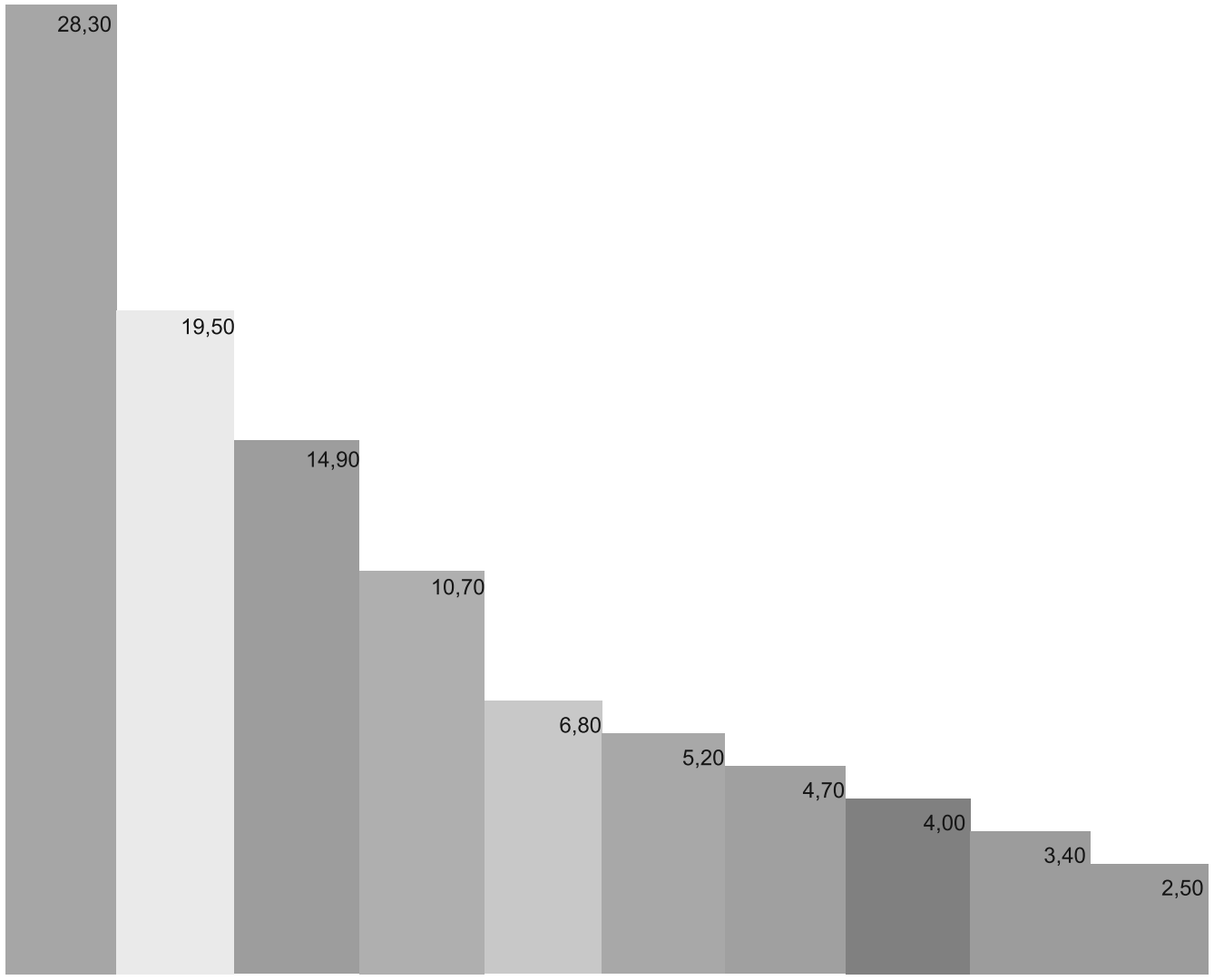

Fig. 2. Reasons for ineffective tutoring of the IWS (teachers' point of view) 
The results of the research showed that most of the teachers $(28.3 \%)$ complain about the absence of electronic resources to organize the IWS and the appropriate automatic assessment tools to make the process of checking and grading easier and not so timeconsuming. Many of the respondents (19.5\%) are awaiting financial appreciation. (Here they refer to the facts when even their students get awarded for any individual projects, their supervisors don't get any benefit, and so no further motivation). It can sound strange, but in some of the departments the reports and the recording of the results and the fulfillment of IWS is not obligatory which causes temptation to make IWS optional for some teachers $(12.9 \%)$. A certain number of teachers $(7.7 \%)$ still find it disappointing that the university does not provide them and the students with sufficient technical equipment necessary for showing the results of the IWS. Together with those $6.8 \%$ who would like to know more about the new methods and technologies of organizing the IWS these groups form the troublesome $80.2 \%$ we can identify as problem areas, which should be tackled first on the IWS quality improvement stage.

The implementation on the TQM principles in the HE can be better illustrated on the famous Plan-Do-Check-Act cycle of Deming, first introduced in 1982 and later used for different management theories (Deming, 1994). This system includes Plan and Do dimensions figure 4, which complement each other, and together they contain ten factors. In this article we try to adopt this scheme to monitor the quality of the individual students work in the teaching process of the HE framework. So, the Check dimension has four factors, and the Action dimension has three factors. With careful planning that conforms to customer requirements, the execution dimension can be very explicit.

Educational organizations should be careful to set up a complete long-term development plan that is executed immediately after planning is completed. Therefore, these two dimensions are discussed together. The chart shows how the side-by-side factors work simultaneously, and up-down factors are executed in order. The Action dimension provides the basis for the TQM evaluations to adjust and correct the wrong strategies in advance. Continuous improvement of the quality of the IWS is the most important thing for IWS management.

\section{EIGHT GROUPS OF CIRCUMSTANCES IN IWS QUALITY MANAGEMENT}

According to the scientific vision of the management structure and purpose of Yevgeniy Khrykov, the Professor of the Luhansk National Taras Shevchenko University, the key role of the HE management is defined as the establishment of the eight groups of circumstances illustrated by Figure 5 . We have already mentioned that the IWS management is seen as an integral part of the general management of a university, obtaining the same aim, structure and procedures. Consequently, we can stipulate the following thesis: IWS quality management involves the formation of the eight groups of circumstances providing the necessary planning, maintaining and monitoring the results of the individual work of students. Under those circumstances necessary to manage the quality of the IWS we understand the following:

The social and prognostic group includes the SWOT analysis of the IWS within the content of the HE and national market needs, development and introduction of the general concept and strategy a university will follow in its IWS policy for a period 


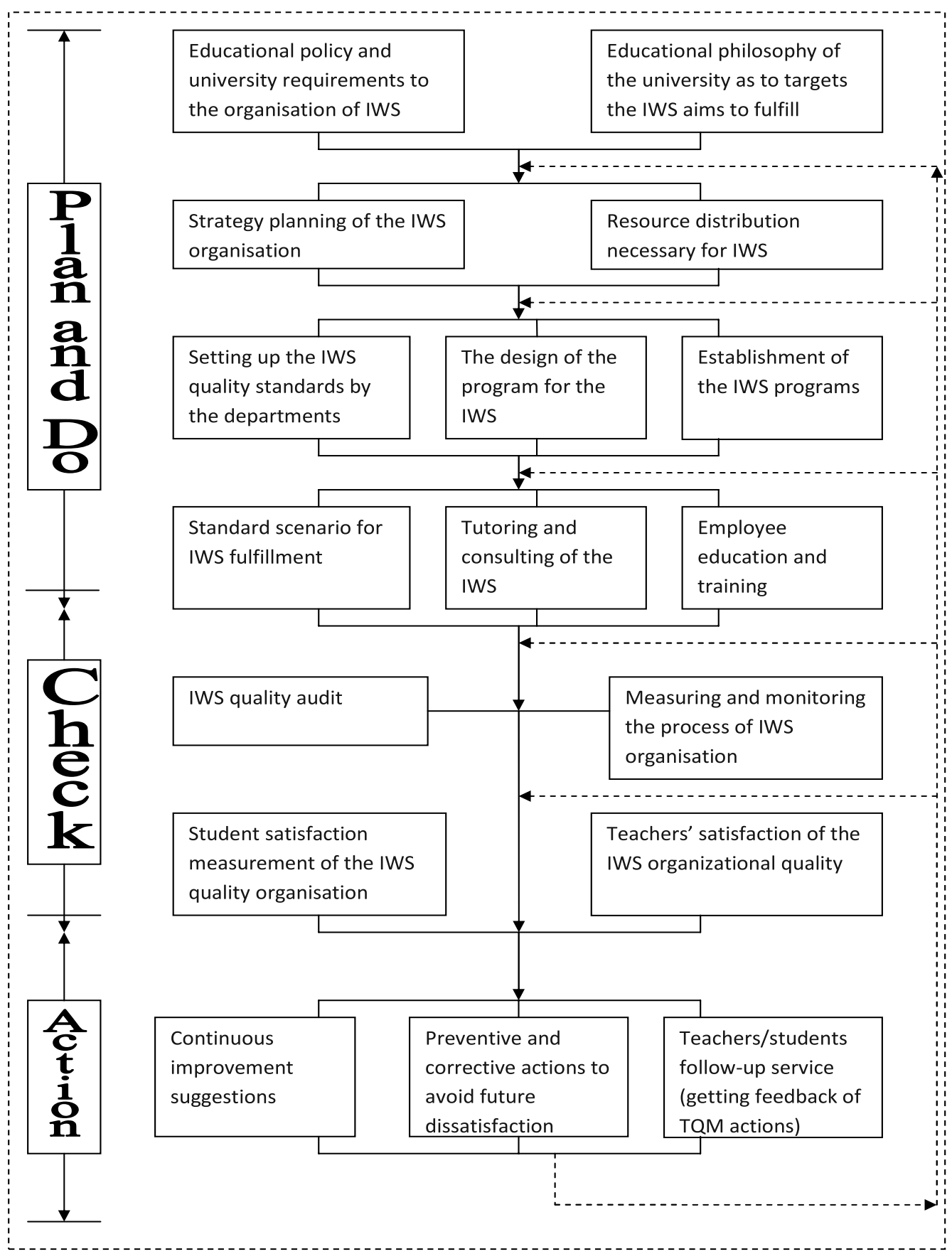

Fig. 4. Quality management of individual students work in $\mathrm{HE}$

Source: author 


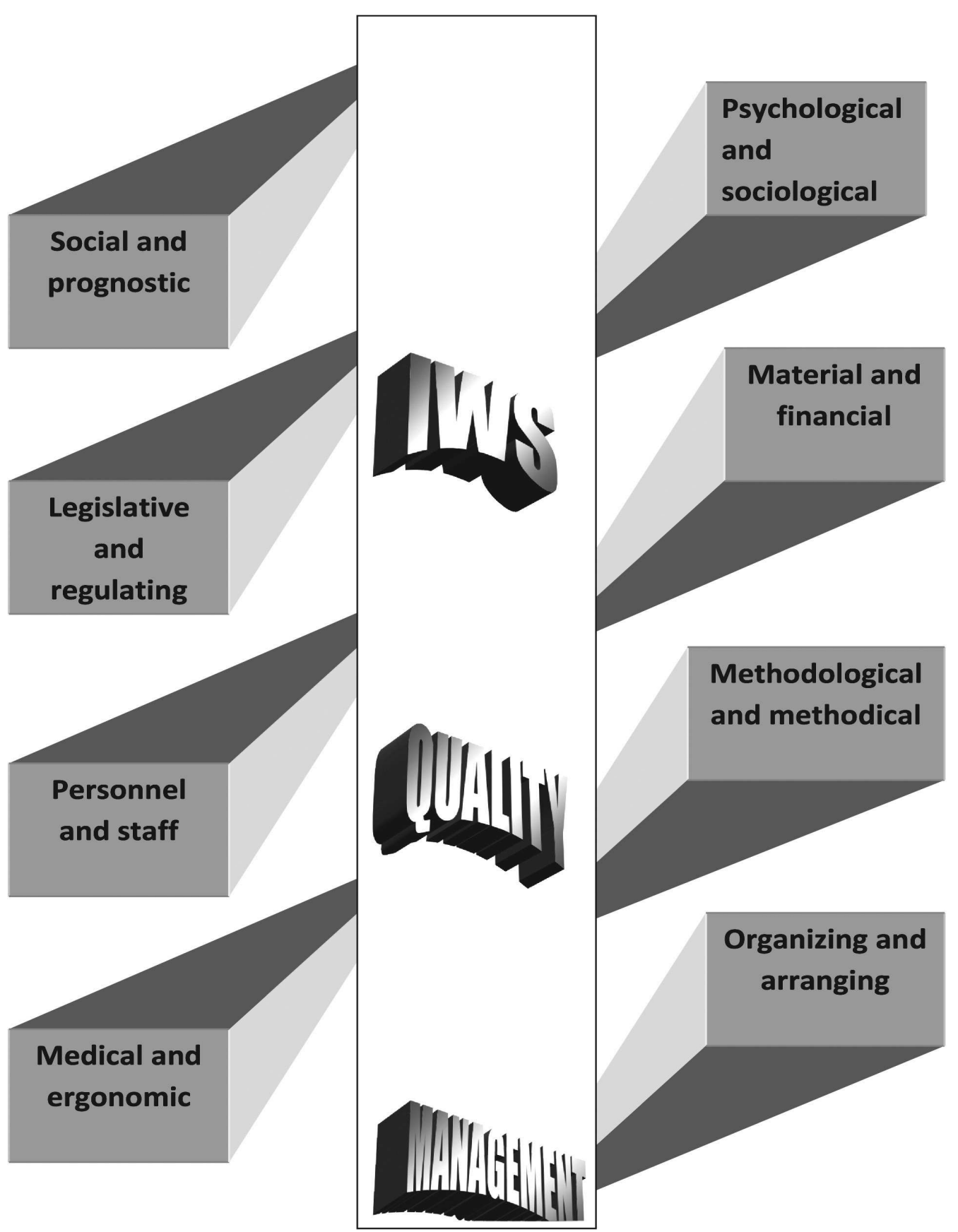

Fig. 5. The structure of the IWS quality management Source: author 
not shorter than 5 years. The target is to foresee and predict the desirable result of the IWS, to draw the ideal model of the most effective IWS process. The legislative and regulating group is aimed to work out the detailed set of laws, instructions, orders and rules the subjects of the educational process would follow providing the standards of size, terms, assessment of the IWS, the set of paper and documents they must prepare for organizing the IWS, the forms of recording reporting the results of the IWS. The personnel and staff group of circumstances focuses on the on-the job training system, which enables the workers (viewed as internal customers) to improve the professional qualification on a constant basis and be aware of the up-to-date methods and technologies applied to IWS.

Medical and ergonomically orientated circumstances must assure the necessary conditions of work and study for both teachers and students in the course of organizing and tutoring IWS (such as light, humidity, space, noise, air temperature, etc.) according to the existing national standards. The HE establishment in Ukraine is assigned to make medical examination records of the workers and learners on a regular basis, to organize the technical safety instructing and check-ups to be sure no one can lose health during IWS.

The psychological and sociological part of the quality management in the course of IWS investigates the degree of readiness of the students to work individually under certain conditions, and teachers, in their turn, to plan, organize and control the certain amount of IWS. Psychological and sociological services must later measure the level of satisfaction of the HE customers (students and teachers) with the IWS organization and give recommendations on what can be done to meet clearly their personal expectations in future.

The material and financial side of the IWS quality management provides the customers (external and internal) with the means of study and work needed for the effective IWS. These means may include: computer classes, multimedia rooms, furniture, books, electronic textbooks, other software and hardware, as well as monetary rewards.

The methodological and methodical block of circumstances is formed to assure that teachers have different sorts of the scientific assistance and statistics data necessary for IWS tutoring, and students - for its completeness (such as subject program, individual plan, texts, exercises, rules of fulfillment).

The organizing and arranging segment of the IWS quality management deals with timetables, time distribution of the IWS throughout the week, semester, curriculum and among the teachers of the same qualification level; collects and delivers information about IWS tasks, terms, and place; is also responsible for the tutoring schedule.

Conclusion

Each of the above mentioned groups of circumstances is equally important for the IWS quality management. Any of them being managed inefficiently can cause the disqualification of the whole process. We cannot say some must be considered as of primary assurance. The one which is weak at the current cycle of management must be corrected first on the improvement stage.

The theoretical background and the practical procedures described in the article prove that the implementation of the IWS quality management within the framework of general HE quality management can sufficiently systematize and improve the quality of the individual students work and, thus, benefit students, teachers and institutional organizations as a whole. The next step to design the system of IWS quality management will be the detailed distribution of the roles and responsibilities the workers should perform in the teaching-learning process. 
Journal of Education Culture and Society No. 2_2014

\section{REFERENCES}

Aisenberg A. (1996). Self-education. The history, the theory and the contemporary problems. The course of lectures for university students. Moscow, 128 pages.

Aly, N., \& Akpovi, J. (2001). Total Quality Management in California Public Higher Education. Quality Assurance in Education, 9(3), 127-131.

Arif, M., \& Smiley, F. (2004). Baldridge Theory into Practice: a working model. International Journal of Educational Management, 18(5), 324-328.

Aspers, Patrik (2001). Crossing the Boundary of Economics and Sociology: The Case of Vilfredo Pareto. The American Journal of Economics and Sociology 60 (2): 519-545

Atkinson A., \& Kaplan R. (2005) Management accounting. Translated by A. Rahubovsky. The third edition. Williams Publishing House. 874 pp.

Avdjieva, M., \& Wilson, M. (2002). Exploring the Development of Quality in Higher Education. Managing Service Quality, 12(6), 372-383.

Babanskij, Y. (1989). The pedagogic science. Moscow: Pedagogika, 560 pages.

Berry, L.L., Marketing services, The Free Press, 1991

Borahan, N. G., \& Ziarati, R. (2002). Developing Quality Criteria for Application in the Higher Education Sector in Turkey. Total Quality Management, 13(7), 913-926.

Becket, N., \& Brookes, M. (2006). Evaluating Quality Management in University Departments. Quality Assurance in Education, 14(2), 123-142.

Brookes, M., \& Becket, N. (2007). Quality Management in Higher Education: a review of international issues and practice. International Journal of Quality and Standards, Paper 3, 1(1), 98-120

Chen, S., Yang, C. (2006). The Application of a Balanced Scorecard in the Performance Evaluation of Higher Education. TQM Magazine, 18(2), 190-205.

Cheng, Y., \& Tam, W. (1997). Multi-Models of Quality in Education. Quality Assurance in Education, 5(1). 22-31.

Como, L. (1986). The metacognitive control components of self-regulated learning. Contemporary Educational Psychology, 11(4), 333 - 346.

Mandinach, E. (1983). The role of cognitive engagement in classroom learning and motivation. Educational Psychology, 18(2), 88-108.

Crosby Philip B. (1994). Quality Without Tears, Singapore: McGraw-Hill.

Deming, W. E. (1994). The New Economics for Industry, Government, Education. Cambridge, MA: Massachusetts Institute for Technology, Center for Advanced Engineering Study, 287 pages.

Dolzhenko O., \& Shatunovskij V. (2005) . Modern methods and technologies of teaching the technical college students. Methodological recommendations for teachers. Moscow, High School Journal. 191 pages.

Ellis, R. (1993) Quality assurance for university teaching. Buckingham, England: The Society for Research into Higher Education and the Open University Press

Esipov B. P. (1961). The individual work of students in the course of learning. The Russian News Journal of the Academy of Pedagogical Sciences, vol.115, 12-24.

Grant, D., Mergen, E., \& Widrick, S. (2002). Quality Management in US Higher Education. Total Quality Management, 13(2), 207-215.

Grant, D., Mergen, E., \& Widrick, S. (2004). A Comparative Analysis of Quality Management in US and International Universities. Total Quality Management, 15(4), 423-438.

Gubarenko O., (2012). The methodological background of the individual work of students management in higher educational establishments. The published materials of the conference: Tendencies of higher education development in Ukraine. Volume1. The Crimea, Yalta, 2012, pp. 75-83.

Gubarenko O., (2013). The concept and the content of the individual work of students in the university system of quality management. The thematic issue: Higher education of Ukraine in the context of Intergration 
to European Educational Space. Supplement 1 to Vol.31, vol.1(43), Kiev, Gnosis, 505-513.

Gubarenko O., (2014). The implementation of the total quality management technology to the system of the individual work of students management. The published materials of the conference: Creating the administrative, social and educational services management system. The theory and the practice. Ukraine, Luhansk, pp. 51-60.

Higher Education Law of Ukraine. kodeksy.com.ua, zakon.rada.gov.ua〉laws/show/2984-14.

Hutchins D. (1992) Achieve total quality. Director Books, 197 pages.

Kaplan R., Norton D., (1992) The Balanced scorecard - Measures that Drive Performance. Harvard Business Review, 25-36.

Khrykov, Y., (2006). Management at educational establishments. Textbook / Y. Khrykov. - Kiev, 365 pages.

Levy-Leboyer C. (2002) Evaluating the personnel. Objectives. Methods. Editional Organisation, 288 p.

Mandinach E., \& Sharnell J. (2012). Transforming teaching and learning through data-driven decision making. Classroom insights from educational psycology. Joint Publication Corwinwith APA Devision 15(259), 50-64.

McAdam, R., \& Welsh, W. (2000). A Critical Review of the Business Excellence Quality Model Applied to Further Education Colleges. Quality Assurance in Education, 8(3), 120-130.

Milliken J. \& Colohan G., 2004. Quality or control. Management in higher education. Journal of higher education policy and management. Volume 26, No.3, November, pp. 381-391.

Mizikaci, F. (2006). A Systems Approach to Programme Evaluation Model for Quality in Higher Education. Quality Assurance in Education, 14(1), 37-53.

Motwani, J., \& Kumar, A. (1997). The Need for Implementing Total Quality Management in Education. International Journal of Educational Management, 11(3), 131-135.

Owlia, M., \& Aspinwall, E. (1996). A Framework for the Dimensions of Quality in Higher Education. Quality Assurance in Education, 4(2), 12-20.

Pidkasistyj P. I. (2004). The essence of the individual students' work and its psychological and didactical basis of its classification. The problem of enhancing the individual students' work. Perm, 124 pages.

Pires da Rosa, M., Saraiva, P., \& Diz, H. (2003). Excellence in Portuguese Higher Education Institutions. Total Quality Management, 14(2), 189-197.

Reid, K., \& Ashelby, D. (2002). The Swansea Internal Quality Audit Processes: a case study. Quality Assurance in Education, 10(4), 237-245.

Roberts, P., \& Tennant, C. (2003). Application of the Hoshin Kanri Methodology at a Higher Education Establishment in the UK. TQM Magazine, 15(2), 82-87.

Ruskin, John (1884). Fors Clavigera: Letters to the Workmen and Labourers of Great Britain, vol. 8, Letters 85-96

Schank, R. (1997). Virtual Learning: A revolutionary approach to building a highly skilled workforce, New York: McGraw-Hill.

Serikov G.N. (1989). The pedagogical basis for improving the process of the students self-study management. Manuscript, Tbilisi, 36 pages.

Shamova T.I. (2002). The systematic approach to the school quality management. School Manager Journal, 2002(8), 92-95.

Sallis Edward, (2005). Total Quality management in higher education. Third edition, Kogan Page, 163.

Shutler P., \& Crawford L. (1998). The Challenge of ISO 9000 Certification in Higher Education. Quality Assurance in Education, 6(3), 152-161.

Srikanthan, G., \& Dalrymple, J. (2003). Developing Alternative Perspectives for Quality in Higher Education. International Journal of Educational Management, 17(3), 126-136.

Srikanthan, G., \& Dalrymple, J. (2004). A Synthesis of a Quality Management Model for Education in Universities. International Journal of Educational Management, 18(4), 266-279.

Tam, M. (2006). Assessing Quality Experience and Learning Outcomes. Part I: Instrument and analysis. Quality Assurance in Education, 14(1), 175-87.

Usova A. V., (1988). The individual work of students. Moscow: Prosveshchenije, 122 pages.

Weinert, F. E., (2001). Concept of competence: A conceptual clarification. In D. S. Rychen, \& L. H. Salganik 
Journal of Education Culture and Society No. 2_2014

(Eds.), Defining and selecting key competencies. Seattle, WA: Hogrefe \& Huber, 45-65

Vries, J. de, (1997). An organisation design methodology for business logistics. In: Proceedings of the 3rd International Symposium on Logistics. Enhancing Competitiveness through Logistics Capabilities, SGE - Servizi Grafici Editoriali, Padova. 69-75

Widrick, S., Mergen, E., \& Grant, D. (2002). Measuring the Dimensions of Quality in Higher Education. Total Quality Management, 13(1), 123-131.

Winter S. G. (1999). The Satisfying Principle in Capability Learning// Strategic Management Journal. 2000. Vol. 21. - N 10-11. - P. 981-996.

Zharaya S. B. (1999) The management system of non-government higher educational establishments in Ukraine. Manuscript, Kiev Taras Shevchenko University Press Center, 188 pages.

Zimmerman, B. J. (2000). Attaining self-regulation: A social cognitive perspective. In M. Boekaerts, P. R. Pintrich, \& M. Zeidner (Eds.), Handbook of self-regulation. San Diego: Academic Press, 13-39.

Zimnyaya I.A. (2005). The social and professional competence as a result of education. The ideal model. Problems of the quality of education. Research center of specialist education quality, Moscow, 10-20.

Zimnyaya I.A. (2003). The key competences as a new paradigm of education. Higher Education Today, №5, 34-42. 